\title{
Relationship Between The Intensity of Noise and Blood Pressure of Operator at PT. Pupuk Iskandar Muda
}

\author{
Cut Saura Salmira ${ }^{1}$ \\ Student of Magister Program Study of Public Health \\ Faculty of Public Health, University of Sumatera Utara, \\ Medan, Indonesia \\ cutsaura.s@gmail.com
}

\author{
Gerry Silaban ${ }^{2}$ \\ Department Occupational Health \\ Faculty of Public Health, University of Sumatera Utara \\ Medan, Indonesia \\ gerry_fkmusu@yahoo.com,
}

\author{
Fazidah Aguslina Siregar ${ }^{3}$ \\ Department of Epidemiology \\ Faculty of Public Health, University of Sumatera Utara \\ Medan, Indonesia \\ fazida65@yahoo.com
}

\begin{abstract}
High noise may cause physiological impact such as increased of blood pressure $( \pm 10 \mathrm{mmHg})$. The source of noise at factories is usually produced from turbine, compressor, pump and other processing equipment. This can affect the blood pressure of operators in PT. Pupuk Iskandar Muda Lhokseumawe fertilizer because it exceeds the threshold value, which is $85 \mathrm{~dB}$. This will lead to health problems such as hearing loss, physiological disorders, to stress that causes the state of irritability, headaches, sleep disorders that result in decreased concentration in the workplace.However this cannot be ignored as it may cause a decrease in performance so that it loses efficiency and productivity. The objective of this study was to determine the relationship between noise intensity with the elevated of blood pressures on the operators at PT. PupukIskandar MudaLhokseumawe. Materials and Methods: This is an observational study with cross-sectional design. The population was 144 operators at PT. PupukIskandarMuda and the samples were 60 people selected using purposive sampling technique. Data analysis was performed using spearman rank test. Results: The results showed that there was not correlation between noise intensity and systolic pressure; however there was correlation between noise intensity and diastolic blood pressure. In this paper showed that the highest noise intensity at PT. Iskandar Muda Lhokseumawe fertilizer was ammonia. Conclusions: It was recommended that the company should conduct the socialization andtraining to operators by using ear protective equipment on a regular basis to reduce the impact of noise.
\end{abstract}

Keywords- Noise Intensity; Blood Pressure; Operator; Correlation; Protective Equipment

\section{INTRODUCTION}

In industrial countries, noise becomes the main problem of health. WHO (2004) noted that almost $14 \%$ of workers in Industrial countries are exposed by noise intensity level $90 \mathrm{~dB}$. In United States of America (USA), approximately 20 million people are exposed by noise intensity level more than $85 \mathrm{~dB}$. Diseases caused by noise are on the first list of occupational diseases in USA and Europe with the proportion of $35 \%$ [1].

Noise is a sound that is not perfect or unexpected and can be developed a person. This noise can be adjusted and can be analyzed in nature. Noise is heard as stimulations at touch by vibrations through elastic media, and sound when not desired, then vice versa as sound [2].

High-pitched noise can lead to physiological reactions such as increased blood pressure $( \pm 10 \mathrm{mmHg})$, increased pulse rate, basalt metabolism, sleep disorder, and others [6].The relationship between noise and health problems is strongly influenced by several factors such as noise intensity, noise frequency and how long someone stays on the place or on the source of the sound. Some studies conducted; found that noise has a negative effect on health, one of which is the effect of noise on the increase of blood pressure [7].Some of researchers relate noise to the risk of hypertension. Likewise, exposure to noise can cause unstable emotions that can trigger stress. Long enough stress will cause the rise of blood pressure, and cause hypertension [10].

Noise disturbances usually occur after years of continuous work in the workplace exposed to noise, while persistent high blood pressure from long-term exposure to noise can lead to complications. As Zulharman (2014) explains to machinist at PT. Kereta Api (Persero) DAOP-IV Semarang that the incidence of NIHL and Hypertension more experienced an increase in blood pressure on workers who work more than 5 years compared to a period of work under 5 years.

Research by Baba says noise can increase systolic and diastolic blood pressure. This research at PT. Semen 
Tonasa Maros shows that there is a significant relationship between noise intensity in the working environment with increased systolic blood pressure and diastolic blood pressure [2].

PT Pupuk Iskandar Muda (PT PIM) is a subsidiary of PT Pupuk Indonesia (Persero) that engaged in urea fertilizer .The factory has several plants including Ammonia plants, Urea plants and Utilities plants and each plant there are a large and noisy machines installed. The noise is usually produced from turbine, compressor, pump and other processing equipment. Machines that produce noise are (Compressor House Turbine) on Ammonia, (Boster Compressor $\mathrm{CO}_{2}$ ) on Urea and machine (Package Boiler) on Utilities.

In the process of fertilizer production, the machines are operated continuously for 24 hours which is handled and controlled by the operator with 3 shifts system in 4 groups. In each plant, every shift consists of 12 operators with 5 (five) operators working in the Operation Center, and 7 (seven) operators are in charge in controlling the operating conditions of the machines in the field, requiring them to use Personal Protection Equipment (PPE/APD). Engine inspection in the field is done 4 hours once with inspection time range from 45 60 minutes with the exposure of noise obtained by each operator 2 hours from 8 hours in every working day. In each plant there is a shelter for workers. At the operator at PT. Iskandar Muda fertilizer works in a noisy area exceeding dB so that workers have a high risk of increased

\section{METHODS}

This research is an observational research using the theory of quantitative with cross sectional approach. The aim of this research is to find the relation between independent and dependent variable; the relation between noise intensity and blood pressure of operator in PT. Pupuk Iskandar Muda Lhokseumawe on 2017.

This research is located at PT. Pupuk Iskandar Muda towards Compressor House Turbinon Ammonia, Booster Compressor CO2 on Urea, and Package Boiler on utilities where the operators are usually located. The research is start on December 2016 - November 2017.Sample Size: The population of this research is the whole operators worked on Ammonia plant, Urea plant, and Utilities plant as many as 144 persons. Where the formula of the sample used is

$$
n=\left(\frac{\left.Z_{\alpha} \sqrt{P o(1-P o}\right)+Z_{\beta} \sqrt{P a(1-P a)^{2}}}{P a-P o}\right)
$$

Information :

$$
\mathrm{n} \quad=\text { Sample Size }
$$

$\mathrm{Z} \alpha=$ The value on the normal curve for $\alpha$ (alpha), that is 1.96

$\mathrm{Z}_{\beta}=$ The value on the normal curve for $\beta$ (Beta) that is 0.842

Po $=$ Proportion of population hypertension at PT.PIM as much as 0.06 on 2017

$\mathrm{Pa}=$ Theapproximate proportion of the proposed proportions with the population proportion is 0.16

$$
\begin{aligned}
n & =\left(\frac{1.96 \sqrt{0.06(0.94)}+0.842 \sqrt{0.16(0.84)^{2}}}{0.16-0.06}\right) \\
& =60 \text { people }
\end{aligned}
$$

This research is using purposive sampling with requirements; the operator's working period is over 5 years, 21-40 years old, do not have hypertension case history, and willing to be included in the research.

The variable in this research are consists of dependent variable that is systolic and diastolic blood pressure at operator and independent variable that is noise intensity. The Study Instrument : This research using Soundlevel Meter to measure noise and measure the blood pressure of the operator by using a Sphygmomanometer. Statistical Analysis : The technique of analysis that will be used to analyze or test the hypothesis that exists in this research is Define Spearman Rank.

\section{RESULT}

Noise at PT. Pupuk Iskandar Muda comes from mentioned three production plants. The final result of noise measurement is:

TABLE I.

NOISE INTENSITY AT PT. PUPUK ISKANDAR MUDA

\begin{tabular}{|l|l|c|c|}
\hline No & Area & Result & NAB \\
\hline 1 & Ammonia(Compressor House Turbin) & $103 \mathrm{~dB}$ & $85 \mathrm{~dB}$ \\
\hline 2 & Urea (BosterCompressor CO2) & $98,9 \mathrm{~dB}$ & $85 \mathrm{~dB}$ \\
\hline 3 & Utilitas (PackageBoiler) & $94,3 \mathrm{~dB}$ & $85 \mathrm{~dB}$ \\
\hline
\end{tabular}

According to the table, shows that there is $103 \mathrm{~dB}$ of noise intensity level at Compressor House Turbine, $98.9 \mathrm{~dB}$ at Booster Compressor CO2 and while for Package Boiler, the noise intensity level is $94.3 \mathrm{~dB}$. The highest Noise Intensity is the Compressor House Turbine.

The average level of noise intensity level of the three plants is $98.51 \mathrm{~dB}$ with SD 3.62. The Intensity of noise at PT. Pupuk Iskandar Muda exceeds the threshold limit value set by the Minister of Manpower and Transmigration in Permenakertrans No.13 / MEN / X / 2011 on Threshold Limit Value for Physical and Chemical Factors in the Workplace. NAB noise as a hazard factor in the workplace is a standard as a guideline of control so that the workforce can still deal with it without causing illness or health problems in the daily work for time not exceeding 8 hours a day and 5 working days a week or 40 hours a week [8]. 
TABLE II

FREQUENCY DISTRIBUTION OF RESPONDENT CHARACTERISTICS OF PT. PUPUK ISKANDAR MUDA

\begin{tabular}{|c|c|c|c|c|c|c|c|c|}
\hline \multirow{2}{*}{$\begin{array}{c}\text { Working } \\
\text { Plants }\end{array}$} & \multicolumn{4}{|c|}{ Age } & \multicolumn{4}{c|}{ Years of Service } \\
\cline { 2 - 9 } & $\mathbf{2}$ & $\mathbf{3 0}$ & \multicolumn{2}{|c|}{$>\mathbf{3 0}$} & \multicolumn{2}{|c|}{$<5$} & \multicolumn{2}{c|}{$>\mathbf{5}$} \\
\hline Ammonia & 18 & 81,8 & 4 & 18,2 & 13 & 59,1 & 9 & 40,9 \\
\hline Urea & 15 & 78,9 & 4 & 21,1 & 5 & 26,3 & 14 & 73,7 \\
\hline Utilities & 13 & 68,4 & 6 & 31,6 & 5 & 26,3 & 14 & 73,7 \\
\hline
\end{tabular}

The result of this research on the workers that works on the three plants, shows from 22 respondents that works on ammonia, 18 workers $(81.8 \%)$ are on the age of $<30$ years old and 4 workers $(18.2 \%)$ are on the age of $>30$ years old. From 19 respondents that works on Urea, 15 worker $(78.9 \%)$ are on the age of $<30$ years old and 4 workers $(21.1 \%)$ are on the age of $>30$ years old.And From 19 respondents that works on Utilities, 13 workers $(68.4 \%)$ are on the age of $<30$ years old and 6 workers $(31.6 \%)$ are on the age of $>30$ years old. For the years of service on three plants above, from 22 workers that work on ammonia, 13 workers $(59.1 \%)$ with $\mathbf{5}$ years of service and 9 workers $(40.9 \%)$ with $>5$ years of service. From 19 workers that works on Urea, 5 workers $(26.3 \%)$ with $\mathbf{5}$ years of service and 14 workers $(73.7 \%)$ with $>5$ years of service. And from 19 workers that works on Utilities, 5 workers $(26.3 \%)$ with $\leq 5$ years of service and 14 workers $(73.7 \%)$ with $>5$ years of service.

TABEL III.

THE AVERAGE OF SYSTOLIC AND DIASTOLIC BLOOD PRESSURE ACCORDING TO PLANTS AT PT.PUPUK ISKANDAR

\begin{tabular}{|c|c|c|c|c|c|}
\hline No & $\begin{array}{c}\text { Dependent } \\
\text { Variable }\end{array}$ & Min & Max & Mean & SD \\
\hline 1 & $\begin{array}{c}\text { Systolic Blood } \\
\text { Pressure }\end{array}$ & 110 & 130 & 124,67 & 6,576 \\
\hline 2 & $\begin{array}{c}\text { Diastolic Blood } \\
\text { Pressure }\end{array}$ & 70 & 90 & 84,67 & 5,957 \\
\hline
\end{tabular}

In this research, the average of systolic blood pressure of operator is 124.67 with SD 6.75, while the average of diastolic blood pressure is 84.67 with SD 5.95.

TABEL IV.

FREQUENCY DISTRIBUTION OF BLOOD PRESSURE (SYSTOLICAND DIASTOLIC) ACCORDING TO PLANTS AT PT.PUPUK ISKANDAR MUDA

\begin{tabular}{|c|c|c|c|c|c|c|c|}
\hline \multirow{2}{*}{$\begin{array}{c}\text { Working } \\
\text { Plants }\end{array}$} & \multicolumn{3}{|c|}{ Systolic (mmHg) } & \multicolumn{3}{c|}{ Diastolic (mmHg) } & \multirow{2}{*}{ Totals } \\
\cline { 2 - 7 } & $\mathbf{1 1 0}$ & $\mathbf{1 2 0}$ & $\mathbf{1 3 0}$ & $\mathbf{7 0}$ & $\mathbf{8 0}$ & $\mathbf{9 0}$ & \\
\cline { 2 - 7 } & \multicolumn{3}{|c|}{$\mathbf{n}$} & \multicolumn{3}{c|}{$\mathbf{n}$} & \\
\hline Ammonia & 4 & 8 & 10 & 3 & 9 & 10 & 22 \\
\hline Urea & 1 & 5 & 13 & 0 & 9 & 10 & 19 \\
\hline Utilities & 1 & 7 & 11 & 0 & 8 & 11 & 19 \\
\hline
\end{tabular}

From the total of 60 samples studied for systolic blood pressure, there were 34 samples which had a quite high blood pressure that is $130 \mathrm{~mm}$ of the three plants. The plant that most experienced high systolic blood pressure is urea plant as many as 13 workers. As for diastolic blood pressure from the three plants studied, there were 31 workers who experienced quite high diastolic blood pressure that is $90 \mathrm{~mm}$. The plant that has the highest diastolic blood pressure is utilities plant of 11 workers.

Research conducted on systolic blood pressure and diastolic on the operator. In the ammonia of 22 operators as a sample of normal systolic blood pressure of 12 persons, 4 (18.2\%) had systolic blood pressure of $110 \mathrm{~mm}$ and 8people (36.4\%) who had $120 \mathrm{~mm}$ systolic blood pressure, has a blood pressure of $130 \mathrm{~mm}$ of 10 people (45.5\%). In the sample Urea examined diunit 19 people. Operators who had normal systolic blood pressure of 6 people, there was 1 person $(5.3 \%)$ who had $110 \mathrm{~mm}$ systolic blood pressureand 5 people (26.3\%) who had $120 \mathrm{~mm}$ systolic blood pressure. While 13 people $(68.4 \%)$ who have high systolicblood pressure $130 \mathrm{~mm}$ tendency. For Utilities unit of 19 samples, 8 subjects had normal systolic blood pressure of 1 person $(5.3 \%)$ who had systolic blood pressure of $110 \mathrm{~mm}$ and 7 people (36.8\%) who had $120 \mathrm{~mm}$ systolic blood pressure while for 11 people $(57.9 \%)$ who had systolic blood pressure of $130 \mathrm{~mm}$.

As for the results of research on diastolic blood pressure, on the ammonia unit of 22 people of the sample there are 12 people who have normal systolic blood pressure. There were 3 people (13.6\%) who had diastolic blood pressure of $70 \mathrm{~mm}$ and 9 people $(40.6 \%)$ who had diastolic blood pressure of $80 \mathrm{~mm}$. While 10 people $(45.5 \%)$ who have diastolic blood pressure $90 \mathrm{~mm}$ high tendency. In a sample of 19 people working in Urea there were 9 people $(47.4 \%)$ who had normal diastolic blood pressure of $80 \mathrm{~mm}$. While 10 people $(52.6 \%)$ who have high diastolic blood pressure 90 $\mathrm{mm}$. In the Utilities unit of 19 samples studied there were 8 people $(42.1 \%)$ whohad normal diastolic blood pressure of 80 mmand 11 people (57.9\%) who had high diastolic blood pressure of $90 \mathrm{~mm}$.

TABEL V

RELATIONSHIP BETWEEN NOISE INTENSITY AND SYSTOLICAND DIASTOLIC BLOOD PRESSURE OF OPERATOR AT PT. PUPUK ISKANDAR MUDA

\begin{tabular}{|c|c|c|c|}
\hline Variable & $\mathbf{n}$ & $\mathbf{r}$ & $\boldsymbol{p}$ value \\
\hline $\begin{array}{c}\text { Noise Intensity towards } \\
\text { systolic blood pressure }\end{array}$ & 60 & 0,242 & 0,280 \\
\hline $\begin{array}{c}\text { Noise Intensity towards } \\
\text { diastolic blood pressure }\end{array}$ & 60 & 0,664 & $<0,001$ \\
\hline
\end{tabular}

The results of this study indicate that there is no relationship between noise intensity and systolic blood pressure $(\mathrm{p}=0,280)$ with value $(\mathrm{r}=0,242)$ means relationship between noise intensity and systolic blood pressure is weak and has positive pattern. As for the relationship between noise 
intensity and diastolic blood pressure $(\mathrm{p}=<0.001)$ with the value $(r=0.664)$ means that the relationship between noise intensity and diastolic blood pressure is strong and has positive pattern which means the relationship between noise intensity for diastolic blood pressure is the higher intensity of noise causing the higher blood pressure of the operator at PT. Pupuk Iskandar Muda Lhokseumawe.

\section{IV.DISCUSSION}

PT. Pupuk Iskandar Muda Lhokseumawe is filled with majority of young workers which are less than 30 years old caused by the job requirements to become an operator only need the qualification of Senior High School graduated, so when the operators start their first day of works, they are approximately 18-20 years old. These situation resulting their years of service are majority above 5 years even they are young.

Noise disturbance can damage the sense of hearing, physiological disorder, stress that leads to a state of irritability, headache, sleep disorder, psychomotor reactions disorder, loss of concentration, concentration disorder between interlocutors which all of them will leads to decreased of work performance that will lose the efficiency and productivity [9].

Most of the workers at PT. Pupuk Iskandar Muda have high blood pressure on urea plants and utilities. Thecause of blood pressure can be triggered by some factors from the physical and psychological work environment. As in the urea plant, where on the urea plant does not have its own shelter. The workspace of the field operator is linked to the panel operator in the control room. There is a gap between the panel operator and the field operator. Besides, only urea plants that do not have shelters, while ammonia plants and utility plants have shelters. As for plant utilities trigger high diastolic blood pressure due to the position of the engine thatcaused noise adjacent to the operator's room. Moreover, the room is not soundproof.

The noise intensity in systolic is weak and has positive pattern because the ammonia plant has the highest noise over the three plants which is $103 \mathrm{~dB}$. However, it gives a little effect on systolic blood pressure due to only 10 operators whose blood pressure is $130 \mathrm{Hg}$ in the ammonia plant compared to the Urea plant that has more of them that is 13 operators even the noise intensity on the Urea plant is lower. As for the high diastolic blood pressure of $90 \mathrm{Hg}$ on the ammonia and urea plant, respectively 10 people are suffered high blood pressure. It is only differ slightly by 11 people in the utilities plant. Many operators that experienced high diastolic blood pressure in Utilities are caused by the position of machine that adjacent to the operator's room, resulting the noises are accumulated to the operator's room. In addition, based on the observation during this research, the intensity of noise on the Ammonia, Urea and Utilities plant at PT. Pupuk Iskandar Muda Lhokseumawe affects blood pressure because the condition is associated with several factors including the old machine and the condition of the machines that are always operated continuously for 24 hours such as compressors and boilers so the sounds issued by the engine directly exposed to the operator. The operator uses ear protection to minimize the effect, but the operator does not adhere to the correct way of PPE so the noises are highly coming into the operator's ear, even though the operator keeps working in very noisy environments. Lack ofsupervision by related parties in the use of Ear Protective Tool makes an adverse impact on operator health.

Increased blood pressure, usually runs together between systolic and diastolic. The setting of blood pressure depends on the control of two main determinants of cardiac output and total peripheral resistance. Control of cardiac outputdepends a lot on setting the heart rate and puffing volume. While total peripheral resistance is primarily determined by the degree of arterial vasoconstriction. Increased heart rate will directly affect systolic blood pressure. While diastolic bloodpressure. More influenced by total peripheral resistance [2].

High-intensity noise can cause dizziness / headaches. This is due to the noise can stimulate the vestibular receptor situation in the inner ear that will cause dizziness / vertigo. Feelings of nausea, insomnia and shortness of breath caused by noise stimulation of the nervous system, organ balance, endocrine glands, blood pressure, digestive system and balance [6].

Liu et.al (2015) shows that the incidence of hypertension was higher in the group that exposed to noise than the control group, $29.2 \%$ vs. $21.2 \%$ ( $p=0.012$ ). Groups that exposed to noise have an increased risk of hypertension, Systolic blood pressure and Diastolic blood pressure in the affected group were significantly higher than the control group $(p=0.006)$. Loss of hearing at these low frequencies was significantly higher in the noise-exposure group than in the control group of $12.8 \%$ vs $7.4 \%(p=0.015)$.

Moreover, in the research done by Chen et.al (2017) shows that noise significantly higher on Systolic $(125,1 \pm 13,9$ $\mathrm{mm} \mathrm{Hg})$ and Diastolic $(77.6 \pm 10.7 \mathrm{~mm} \mathrm{Hg})$ compared to the controlled groups $(117.2 \pm 15.7 \mathrm{~mm} \mathrm{Hg} ; 70.0 \pm 10,5 \mathrm{~mm} \mathrm{Hg})$ $(\mathrm{p}<0.001)$. This research results also shows that there is a significant affect between exposed noise and blood pressure ( $\mathrm{p}$ $<0.001$ ). Compared to the controlled group, subjects with noise exposed hasthe risk of hypertension with $\mathrm{OR}=$ $1.941(95 \% \mathrm{CI}=1.471-2.561)$

\section{CONCLUSIONS}

1. The highest noise intensity at PT. Pupuk Iskandar Muda Lhokseumawe Year 2017 is in Ammonia plant.

2. For $130 \mathrm{~mm}$ of systolic blood pressure are the most in urea plant and for $90 \mathrm{~mm}$ of diastolic pressure are most in utilities plant.

3. The relationship between noise intensity of systolic and diastolic blood pressure are; for noise intensity and systolic blood pressure, the relation is weak and has a positive pattern, while for the relation between noise intensity and diastolic, the relation is strong and has a positive pattern. 


\section{RECOMMENDATIONS}

1. The company should improves surveillance, as well as regular measurements conducted (once a month) to determine the noise level, where known noise sources exceed the Threshold Limit Value (TLV/NAB).

2. Engineering Technology is recommended to the company to reduce the noises whether at the field or operator's shelter.

3. Increase the worker discipline in the use of Personal Protective Equipment (PPE/APD) such as ear plug to reduce noise intensity exposure above TLV at work correctly.

\section{ACKNOWLEDGMENT}

The authors would like to thank Dr.Gerry Silaban and Fazidah Aguslina,Ph.D, supervisors, and to the public health faculty of the University of North Sumatra, who provided support to conduct research at PT. Iskandar Muda Lhokseumawe. The authors are also grateful to PT. Iskandar Muda Lhokseumawe, to provide facilities related to data collection. We sincerely thank the anonymous referees and editors for their critical comments and comments.

\section{REFERENCES}

[1] B. Arief, M. Masyitah, and W. Andi, "Relation of noise intensity with job stress on domini airport officer workers eduard Osok Sorong,’Journal Section K3, FKM Hasanudin University, 2014.

[2] Baba, "The relationship between noise intensity in work with increased blood pressure," Thesis Master of Environmental Health Diponegoro University of Semarang,2007.

[3] C. Shuchang, N.Yaqin, Z.Lei, K.Liya, L. Luying, Y. Zhangping, Y. Luoxian, Z. Xuhui, and Z. Yimin,"Noise exposure inoccupotional setiing associated with elevated blood pressure in china," BMC Public Health, vol. $7: 107,2017$.

[4] L. Jing, X. Ming, D. Lu, Z. Hengdong, P. Liping, L. Qingdon, D. Enming, Z. Qiuni, W. Boshen, H. Lei, Y. Dandan, and Z. Baoli, "Prevalence of hypertension and noise-induced hearing loss in chinese coal miners," Journal of Thoracic Diaseas, vol. 8(3): 422-429, 2016.

[5] Permenakertrans No.13 / MEN / X / 2011 on Threshold Limit Value for Physical and Chemical Factors in the Workplace.

[6] Soeripto, Industrial Hygiene. Faculty of Medicine University of Indonesia,2008.

[7] S.Shinly Montolalu,"Relationship of blood pressure to field workers ptgapura angkasa at sam ratulangi airport manado. Journal of the Faculty of Medicine," University of Sam Ratulangi Manado, Vol 2, No.1,2014.

[8] Suma'mur, Higiene Perusahaan dan Kesehatan Kerja (Hiperkes), Sagung Seto, Jakarta, 2013

[9] Tarwaka, Ergonomics Industrial Basics Knowledge of Ergonomics and Applications In The Workplace. Surakarta,Harapan Press, 2010.

[10] T.Johan Amnon, R. Rum, dan M. Mashita, "Relationship between noise intensity and the hypertension of production labour in pt. sermani steel makasar,'Journal Occupational Health and Safety of Hasanudin University, 2013.

[11] Zulharman, "Relationship noise with blood pressure on employees production section pt. semen tonasa," Health and Safety Section of FKM Hasanuddin University, 2015. 